J. Clin. Chem. Clin. Biochem.

Vol. 19, 1981, pp. 1189-1191

\title{
Gas-Liquid Chromatographic Determination of Mexiletine in Human Serum with Nitrogen Sensitive Detection
}

\author{
By Sirkka M. Elfving, Eivor H. Svens and E. E. A. Leskinen
}

\section{Kivelä Municipal Hospital Labóratory, Helsinki, Finland}

(Received June 12, 1981)

Summary: A simple and rapid method for the quantitative determination of mexiletine, using gas-liquid chromatography with nitrogen sensitive detection, is described. Only one extraction step is needed, the recovery is between $92-96 \%$ and the precision varies between $2.0-5.5 \%$. The lower limit of detection reached $0.5 \mu \mathrm{mol} / 1$. During routine handling the method was easy, quick and cheap.

\section{Gaschromatographische Bestimmung von Mexiletine im Serum mit Stickstoffdetektor}

Zusammenfassung: Eine einfache und schnelle Bestimmungsmethode für Mexiletine im Serum mittels Gaschromatographie mit Stickstoffdetektor wird beschrieben. Eine einmalige Extraktion ist ausreichend, die Wiederfindungsrate beträgt 92-96\%, die Genauigkeit variiert zwischen 2,0 und 5,5\%. Die Nachweisgrenze liegt bei 0,5 $\mu \mathrm{mol} / 1$. Im Rahmen von Routinebestimmungen hat sich die Methode als spezifisch, zeitsparend und billig erwiesen.

\section{Introduction}

Mexiletine (1-(2,6-dimethylphenoxy)-2-aminopropane is an anti-arrhythmic drug which is effective when administered orally or intravenously $(1,2)$. Mexiletine has been used in the treatment of acute and chronic ventricular arrhythmias associated with various cardiac diseases (3-6). The quantitative determination of mexiletine is important both for monitoring and optimizing blood levels of patients receiving therapeutic doses, and for studying the pharmacokinetic properties of the drug $(7$, $8,9)$. Several gas-liquid chromatographic methods are available for measuring the circulating concentrations of mexiletine $(10-15)$. In addition to flame-ionization detection (FID) $(12,13)$ both electron-capture (EC) (11) and nitrogen selective detection (NPD) $(14,15)$ have been employed. Although the methods appear to be specific and accurate they tend to be tedious and lengthy, and thus not suitable for the rapid manual analysis of multiple samples. The aim of the present study was to evaluate a simple, rapid and accurate gasliquid chromatographic determination of mexiletine using nitrogen sensitive detection.

\section{Materials and Methods}

Reagents

Mexiletine hydrochloride, 1-(2,6-dimethylphenoxy)-2-aminopropane x HCl, Kö $1173 \mathrm{Cl}$, C. H. Boehringer Sohn, D-6507 Ingelheim am Rhein, F.R.G., $M_{\mathrm{r}}=214.7$.

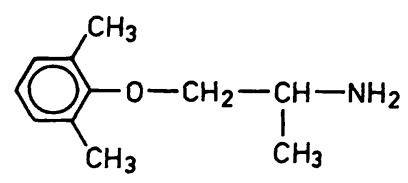

Fig. 1. Molecule structure of mexiletine, $M_{\mathrm{r}}=179.3$.

Stock standard solution: $5.0 \mathrm{mmol} / 1$ in distilled water. Stored at $+4{ }^{\circ} \mathrm{C}$.

Working standard: $2.5,5.0,10.0$ and $15.0 \mu \mathrm{mol} / 1$ in pooled, drugfree serum. Aliquots of $1 \mathrm{ml}$ were stored at $-20^{\circ} \mathrm{C}$.

Internal standard, 1-(2,4,6-trimethylphenoxy)-2-aminopropane $X \mathrm{HCl}, \mathrm{Kö} 1307 \mathrm{Cl}, \mathrm{C}$. H. Boehringer Sohn, D-6507 Ingelheim am Rhein, F.R.G.

Stock solution: $4.0 \mathrm{mmol} / 1$ in distilled water. Stored at $+4{ }^{\circ} \mathrm{C}$. Working solution: $40.0 \mu \mathrm{mol} / 1$ in distilled water. Stored at $+4{ }^{\circ} \mathrm{C}$.

Sodium hydroxide (Merck No. 9136, E. Merck, D-6100 Darmstadt, F.R.G.): $2 \mathrm{~mol} / \mathrm{l}$.

Diethyl ether (Merck No. 921, E. Merck, D-6100 Darmstadt, F.R.G.).

Acetic anhydride (Merck No. 42, E. Merck, D-6100 Darmstadt, F.R.G.).

Methanol (Merck No. 6002, E. Merck, D-6100 Darmstadt, F.R.G.).

Gas chromatographic conditions

The gas chromatograms were obtained with a Varian 2100 gas chromatograph equipped with a flameless nitrogen/phosphorussensitive detector (Thermionic Specific Detector, Varian Associates, U.S.A.) and a Servogor RE 511 recorder (Goertz Electro, Austria). 
The glass column ( $1.1 \mathrm{~m}$ length and $2 \mathrm{~mm}$ inside diameter) was filled with $10 \%$ SP-1000 on Supelcoport $80 / 100$ mesh (Supelco, INC., Bellefonte, Pennsylvania 16823).

The column oven temperature was $180^{\circ} \mathrm{C}$, and the injector and detector temperatures were both $220^{\circ} \mathrm{C}$.

The flow rates of the nitrogen carrier gas, hydrogen and air, were $20 \mathrm{ml} / \mathrm{min}, 4.5 \mathrm{ml} / \mathrm{min}$ and $175 \mathrm{ml} / \mathrm{min}$ respectively.

\section{Procedure}

To a serum sample $(1 \mathrm{ml}) 200 \mu \mathrm{l}$ of the internal standard solution and $400 \mu \mathrm{l}$ of sodium hydroxide $(2 \mathrm{~mol} / \mathrm{l})$ are added. After mixing, the sample is extracted by shaking for 10 minutes two times with $3 \mathrm{ml}$ portions of diethyl ether. The upper ether layers are transferred into' a tapered glass centrifuge tube. To make the acetyl derivative of mexiletine $25 \mu \mathrm{l}$ of acetic anhydride is added to the ether solution. The ether is evaporated off in a thermostated bath at $40^{\circ} \mathrm{C}$. The residue is dissolved in $25 \mu$ of methanol using a vortex mixer. Aliquots of $1 \mu \mathrm{l}$ are injected into the gas chromatograph.

Working serum standards are processed for each batch of samples. A four-point calibration curve is constructed from which the mexiletine concentrations are read. The retention times for mexiletine is $1.8 \mathrm{~min}$ and for the internal standard $2.3 \mathrm{~min}$. Linearity is good from $0.5 \mu \mathrm{mol} / 1$ to $40.0 \mu \mathrm{mol} / 1$.
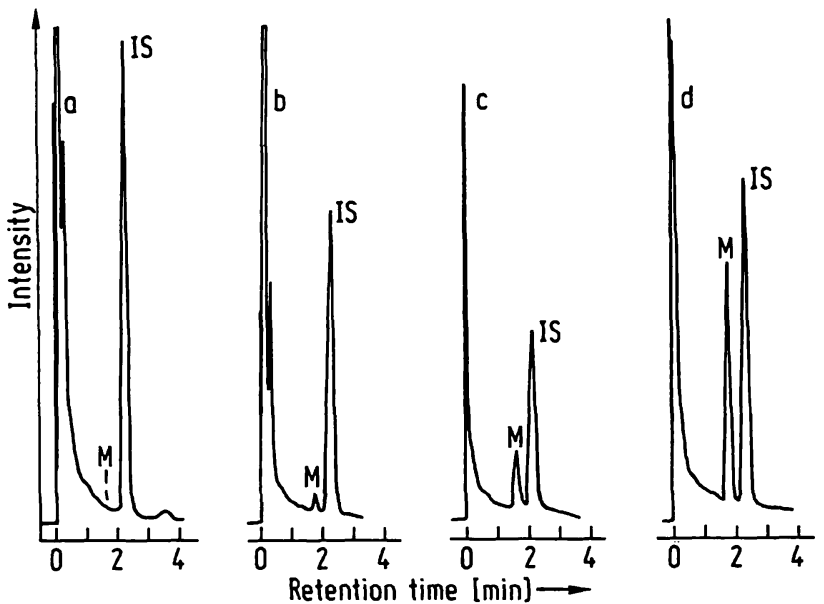

Fig. 2. Gas chromatograms:
a) blank serum
b) serum containing $0.5 \mu \mathrm{mol} / 1$ mexiletine (M)
c) serum containing $2.5 \mu \mathrm{mol} / 1$ mexiletine (M)
d) serum containing $7.3 \mu \mathrm{mol} / 1$ mexiletine (M)
IS $=$ Internal standard

\section{Results and Discussions}

\section{Specificity and sensitivity}

Representative chromatograms of serum samples extracted according to our procedure are presented in figure 1. Chromatogram (a) is a pattern typical of the serum of a normal individual not receiving drugs. Chromatogram (b) is obtained from a standard solution (in serum) containing $0.5 \mu \mathrm{mol} / 1$ mexiletine. Chromatogram (c) and (d) are obtained from a patient who first received $3 \times 200 \mathrm{mg}$ mexiletine (c) and then $2 \times 400 \mathrm{mg}$ mexiletine a day (d) resulting in serum concentrations of $2.5 \mu \mathrm{mol} / 1$ and $7.3 \mu \mathrm{mol} / 1$ respectively. No interference was found from endogenous serum constituents, or in serum from patients treated with digitalis, betablockers, benzodiazepines or different diuretics.

In order to test the sensitivity of the method in sensitivity studies a drug free serum was spiked with mexiletine to a concentration of $0.5 \mu \mathrm{mol} / 1$ and processed as described above. The limit of detection was shown to be less than $0.5 \mu \mathrm{mol} / 1$.

\section{Recovery}

Recovery of mexiletine from serum was studied by adding known quantities of mexiletine to a pre-analysed serum pool. The concentration obtained is given as a percentage of the calculated concentration. This was carried out for two concentrations of added mexiletine.

Ten samples were analysed at both concentrations.

Tab. 1. Recovery of mexiletine from serum $(\mathrm{N}=10)$.

\begin{tabular}{llll}
\hline $\begin{array}{l}\text { Initial } \\
\text { concentration } \\
(\mu \mathrm{mol} / \mathrm{l})\end{array}$ & $\begin{array}{l}\text { Calculated } \\
\text { concentration } \\
(\mu \mathrm{mol} / \mathrm{l})\end{array}$ & $\begin{array}{l}\text { Measured } \\
\text { concentration } \\
(\mu \mathrm{mol} / \mathrm{l})\end{array}$ & $\begin{array}{l}\text { Recov- } \\
\text { ery } \\
(\%)\end{array}$ \\
\hline 2.2 & 8.6 & 7.9 & -91.9 \\
2.2 & 14.6 & 14.0 & 95.9 \\
\hline
\end{tabular}

\section{Precision}

Within-run precision was calculated from measurements at three different concentrations.

Day-to-day precision was calculated from mexiletine analysis of a pooled serum over a period of two months.

Tab. 2. Precision of mexiletine assay in serum.

\begin{tabular}{lllll}
\hline & Within-run & & $\begin{array}{l}\text { Day-to- } \\
\text { day }\end{array}$ \\
\hline Mean $(\mu \mathrm{mol} / \mathrm{l})$ & 1.9 & 7.6 & 13.2 & 6.9 \\
SD $(\mu \mathrm{mol} / 1)$ & 0.08 & 0.15 & 0.32 & 0.38 \\
CV $(\%)$ & 4.2 & 2.0 & 2.4 & 5.5 \\
$\mathrm{~N}$ & 20 & 20 & 20 & 14 \\
\hline
\end{tabular}

\section{Conclusion}

Gas-liquid chromatography with nitrogen-sensitive detection of the acetyl derivative of mexiletine provides a rapid and specific method for estimation of its concentration in serum. The method described has been found suitable for routine monitoring of serum concentrations in patients receiving mexiletine. The nitrogen sensitive detector has the advantages of a much șmaller solvent front, increased sensitivity to nitrogen-containing compounds and decreased interference from compounds which do not contain nitrogen. Analyses can thus be 
completed in a shorter time when using a conventional flame detector. For those laboratories in which a gas chromatograph with a nitrogen sensitive detector is available, the present method is fast and simple, while retaining good accuracy and precision. Complete analysis time for an urgent determination is 1.5 hours, while in routine analysis the determination of 30 serum samples may be performed in a normal working day.

\section{References}

1. Talbot, R. G., Clark, R. A., Nimmo, J., Neilson, J. M. M., Julian, D. G. \& Prescott, L. F. (1973) Lancet II, 399-404.

2. Talbot, R. G., Julian, D. G. \& Prescott, L. F. (1976) Amer. Heart J. 91, 58-65.

3. Campbell, N. P. S., Kelly, J. G., Adgey, A. A. J. \& Shanks, R. G. (1978) Brit. J. Clin. Pharmacol. 6, 103-108.

4. Danilo, P. (1979) Amer. Heart J. 79, 399-403.

5. Chew, C. Y. C., Collett, J. \& Singh, B. N. (1979) Drugs 17, $161-181$.

6. Stavenow, L., Hanson, A. \& Johansson, B. W. (1979) Acta Med. Scand. 205, 411-415.

7. Beckett, A. H. \& Chidomere, E. C. (1977) Postgrad. Med. J. 53 (Suppl. 1), 60-66.

8. Baudinet, G., Henrard, L., Quinaux, N., El Allaf, D., De Landsheere, C., Carlier, J. \& Dresse, A. (1980) Acta Cardiol. (Suppl. XXV), 55-65.

9. Bogaert, M. (1980) Acta Cardiol. (Suppl. XXV), 67-73.

10. Kelly, J. G., Nimmo, J., Rae, R., Shanks, R. G. \& Prescott, L. F. (1973) J. Pharm. Pharmacol. 25, 550-553.

11. Frydman, A., Lafange, J.-P., Vial, F., Rulliere, R. \& Alexandre, J.-M. (1978) J. Chromatogr. 145, 401-411.

12. Kelly, J. G. (1977) Postgrad. Med. J. 53 (Suppl. 1), 48-49.

13. Holt, D. W., Flanagan, R. J., Hayler, A. M. \& Loizou, M. (1979) J. Chromatogr. 169, 295-301.

14. Smith, K. J. \& Meffin, P. J. (1980) J. Chromatogr. 181, 469-472.

15. Bradbrook, I. D., James, C. \& Rogers, H. J. (1977) Brit. J. Clin. Pharmacol. 4, 380-381.

Dr. S. Elfving

Kivelä Municipal Hospital Central Laboratory

Sibeliuksenkatu 12-14

SF-00260 Helsinki 26 
